\title{
Multilayer hybrid polypropylene composite with single and wood-polymer composites layers
}

\author{
Artur Kościuszko1), *), Tomasz Sterzyński²), Kazimierz Piszczek ${ }^{3)}$ \\ DOI: dx.doi.org/10.14314/polimery.2018.11.3
}

\begin{abstract}
Single polymer composites (SPCs) are relatively new type of composite materials where reinforcement and matrix are made of the same polymeric material or the same group of materials. The favorable mechanical properties of SPC are due to the macromolecular orientation of fibers or tapes used in their production. This paper presents the results of selecting the most favorable SPC manufacturing process temperature and the use of such materials for a three-layer polypropylene composite production, where the core layer is made of $50 \mathrm{wt} \%$ filler polypropylene-wood composite (WPC). The developed material reveals better mechanical bending properties, compared to unfilled polypropylene and to traditional WPC with $30 \mathrm{wt} \%$ wood flour content.
\end{abstract}

Keywords: single polymer composites, wood-polymer composites, multilayer materials, polypropylene.

\section{Wielowarstwowy hybrydowy kompozyt polipropylenowy z warstwami kompozytu jednopolimerowego i polimerowo-drzewnego}

Streszczenie: Kompozyty jednopolimerowe (SPC) to stosunkowo nowy rodzaj materiałów kompozytowych, w których wzmocnienie i osnowa są wykonane z tego samego materiału polimerowego lub materiałów należących do tej samej grupy. Korzystne właściwości mechaniczne SPC zawdzięczają orientacji makrocząsteczkowej, występującej we włóknach lub taśmach zastosowanych w ich produkcji. Przedstawiono wyniki doboru najkorzystniejszej temperatury procesu wytwarzania SPC oraz zastosowanie tego typu materiałów do wytwarzania trójwarstwowego kompozytu polipropylenowego, w którym warstwę rdzeniową wykonano z kompozytu polipropylenowo-drzewnego (WPC) zawierającego $50 \%$ mas. mączki drzewnej. Opracowany materiał charakteryzuje się korzystniejszymi właściwościami mechanicznymi przy zginaniu niż nienapełniony polipropylen lub tradycyjny WPC o zawartości $30 \%$ mas. mączki drzewnej.

Słowa kluczowe: kompozyty jednopolimerowe, kompozyty polimerowo-drzewne, materiały wielowarstwowe, polipropylen.

Application possibilities of polymeric materials due to its favorable physical properties and relatively low prices allow for significant improvement in many industrial branches, such as the automotive, aerospace, electronics, and medical industry. Important features of polymeric materials and its composites are their relatively low density and simple processing procedure. An approval of interest in polymeric materials brings about a continuous increase in world production, that reached 322 million

\footnotetext{
1) University of Science and Technology, Department of Material Engineering and Polymers Processing, Kaliskiego 7, 85-796 Bydgoszcz, Poland.

2) Poznan University of Technology, Department of Polymer Processing, Piotrowo 3, 60-965 Poznan, Poland.

3) University of Science and Technology, Department of Polymer Technology and Protective Coatings, Seminaryjna 3, 85-326 Bydgoszcz, Poland.

*) Author for correspondence; e-mail: artkos@utp.edu.pl
}

tons in 2015, which is an increase of more than $19 \%$ comparing to 2010.

The widespread use of polymeric materials in the industry is also a result of the wide range of modifications, that can be made to adjust the properties of the materials to the specific needs. One of the most widely modified thermoplastics today is an isotactic polypropylene [1-3], wherein the desired performance properties are most often obtained by filling polypropylene matrix with various types of modifiers, such as talc $[4,5]$, chalk [6,7], and glass fibers [8-10]. Nevertheless, in recent years increasing role is played by natural fillers of plant origin, especially shredded wood particles [11-13].

Wood-polymer composites (WPC) are characterized by lower price comparing to unfilled matrix, due to the availability of wood-based materials. The significant advantages are also usually higher flexural strength and higher elastic modulus, which is achieved in particular by using of compatibilizers or/and modifications of the 
filler surface [14-16]. However, a significant decrease of the impact strength, observed along with increasing filler content, is due to introducing wood particles into the polypropylene matrix [17-19].

Another group of heterophasic polypropylene materials, which is currently of great interest to researchers, are single polymer composites (SPCs) [20, 21]. In these materials matrix and reinforcement are made of the same kind of polymer or polymers of the same group [22-30]. Thanks to the macromolecular orientation in the reinforcing elements of SPC, these composites reveal favorable mechanical properties. In addition, the use of polymeric fibers or tapes as reinforcement results in relatively low density of these composite materials. Single polymer composites are commonly produced by hot compaction of oriented polymer fibers. This technique was developed at the University of Leeds (UK) [31-34]. The principle of this process is the integration of oriented fibers or polymeric tapes by selective melting their outer layers at a certain temperature and pressure. After heating the fibers to the defined temperature, their thin outer layers melt and fill tightly the spaces between the individual filaments. During cooling, the molten material recrystallizes and forms a matrix that binds the entire structure of the composite, where the non-melted core layers of fiber serve as reinforcement of the structure.

Another commonly used method is the compression molding of two-component fibers or tapes, introduced by team of researchers from Queen Mary University in London, Eindhoven University of Technology and Lankhorst Indutech BV in the Netherlands [35-38]. The fiber core is usually a polypropylene homopolymer, and the outer layer is a random propylene-ethylene copolymer. This allows for a widening of the processing window by up to $20-30^{\circ} \mathrm{C}$, which in consequence reduces the risk of relaxing of the oriented macromolecules structure and loss their excellent mechanical properties existing in highly oriented fibers.

Structural composites production is an interesting field of polypropylene single polymer composites application [39]. In this case SPC can act as external reinforcement layers, being an alternative to commonly used materials based on thermosets reinforced with glass, carbon or natural fibers. Various types of porous materials or honeycomb structures are commonly used as lightweight core elements.

The purpose of the research was to improve the mechanical properties of WPC, by joining the layer of wood-polypropylene composite with layers of single polymer composite. The significant advantage of the developed multilayer composite materials, apart from good mechanical properties and low density, should also be their ease of material recycling. One of the assumptions of the multilayer polypropylene composite concept was the attempt to join WPC layer with polypropylene single polymer composite, only by thermal treatment, without use of any additional adhesive materials.

\section{EXPERIMENTAL PART}

\section{Materials}

The round-woven, commercial polypropylene fabric (PP), produced by Stradom S.A. (Częstochowa, Poland), has been applied as material for the SPC layers production. The width of the canvas weave fabric sleeve was $1000 \mathrm{~mm}$, with an average weight of $2 \cdot 70 \mathrm{~g} / \mathrm{m}^{2}$ (two layers). The width of the single strip forming the fabric was $2.5 \mathrm{~mm}$ and the thickness was $0.03 \mathrm{~mm}$. The polypropylene used to produce the fabric contained $10 \mathrm{wt} \%$ of solid filler, confirmed by thermogravimetric measurement.

An isotactic polypropylene Moplen HP 500N, Basell Orlen Polyolefins (Płock, Poland), with a melt mass flow rate $M F R\left(230^{\circ} \mathrm{C}, 2.16 \mathrm{~kg}\right)$ equal to $12 \mathrm{~g} / 10 \mathrm{~min}$ was used as a matrix of the WPC composite. The wood flour Lignocel C 250 S, J. Rettenmaier \& Söhne GmbH \& Co KG (Germany), was applied as a reinforcement of the WPC. The size of wood particles was in the range between 200 and $300 \mu \mathrm{m}$.

\section{Apparatus}

Single polymer and wood-polymer composite, as well as multilayer composites were produced by compression molding. The hydraulic press with a $125 \mathrm{~mm}$ diameter piston and a laboratory mold with interchangeable frames, that allowed the production of sample plates with a thickness of 1,2 and $4 \mathrm{~mm}$, have been applied. The press was equipped with heating plates with dimensions of $250 \times 250 \mathrm{~mm}$, operating with a flat $1000 \mathrm{~W}$ resistance heater. The compression mold consisted of three parts: bottom plate, replaceable frame with cavity dimensions of $120 \times 120 \mathrm{~mm}$, and top plate with drilling allowing to cool the plates.

\section{Compression molding conditions}

Plates with the thickness of $1 \mathrm{~mm}$ (SPC), $2 \mathrm{~mm}$ (WPC) and $4 \mathrm{~mm}$ (multilayer composite) were produced by compression molding. The $1 \mathrm{~mm}$ SPC sheets were obtained by hot compaction, using a stack of 16 sheets of $120 \times 120 \mathrm{~mm}$ PP fabric, placed in a heated (about $80^{\circ} \mathrm{C}$ ) mold cavity. The PP tapes forming the fabric were placed at $90^{\circ}$ and $180^{\circ}$ angle relative to the edge of the mold cavity. The mold was placed between the heating plates of the hydraulic press, compressed with clamping force of $122 \mathrm{kN}$ and heated to the temperature ranging from $174{ }^{\circ} \mathrm{C}$ to $198^{\circ} \mathrm{C}$ at $4{ }^{\circ} \mathrm{C}$ intervals. After 5 minutes of heating, the mold was cooled below $100^{\circ} \mathrm{C}$.

The first step in production of WPC sheets was a homogenization of the raw materials by means of rolling, using a Buzuluk mill roller. Before introduction of wood filler into the polypropylene matrix, the filler was dried with a hot air for 2 hours at $110^{\circ} \mathrm{C}$. The composition of the WPC was $1: 1$ of PP granulates and wood filler. During homogenization, done by mill roller the rolls temperature 
T a b l e 1. Characteristics of multilayer polypropylene composites

\begin{tabular}{c|c|c|c}
\hline Layer & Function & Composition & Thickness, mm \\
\hline 1 & Outer layer & SPC (self-reinforced PP) & $\sim 1$ \\
2 & Core layer & WPC 50\% (PP with 50 wt \% of wood filler) & $\sim 2$ \\
3 & Outer layer & SPC (self-reinforced PP) & $\sim 1$ \\
\hline
\end{tabular}

was $180^{\circ} \mathrm{C}$, the gap between the rollers was variable during the process and ranged from $0.1 \mathrm{~mm}$ at the beginning of rolling to $4 \mathrm{~mm}$ at the end. The product obtained in this way, with $50 \%$ by weight of wood flour (WPC 50\%), was grounded using a high speed mill. Particles with dimension superior than $2 \mathrm{~mm}$ were used to produce WPC sheets by compressing molding, realized with a compression mold temperature of $185^{\circ} \mathrm{C}$. Other processing conditions applied by production of WPC plates, with a thickness of $2 \mathrm{~mm}$, were similar to those of SPC production.

The multilayer sandwich composite with a thickness of $4 \mathrm{~mm}$, consisting of two outer layers of $1 \mathrm{~mm}$ each (SPC) and a core layer of $2 \mathrm{~mm}$ thickness (WPC), denoted as SWS (SPC + WPC + SPC), were produced by compression molding at mold temperature of $178^{\circ} \mathrm{C}$ (Table 1$)$. Moreover, $4 \mathrm{~mm}$ thick panels of unfilled PP Moplen HP $500 \mathrm{~N}$ and the WPC composite containing $30 \mathrm{wt} \%$ wood filler (WPC 30\%) were made as reference material to evaluate the properties of multilayer composites. The mold temperature in this case was $185^{\circ} \mathrm{C}$. Other processing parameters for multilayer composites and reference materials were kept the same as for SPC and WPC production.

\section{Methods of testing}

- The relationship between the mechanical properties and temperature of compression molding of single polymer composites was analyzed by means of the static tensile test. The measurements were performed using a Zwick/Roell Z030 universal testing machine, with a $30 \mathrm{kN}$ force measuring head, operating with a elongation rate of $1 \mathrm{~mm} / \mathrm{min}$ by the determination of the elasticity modulus, and with a rate of $20 \mathrm{~mm} / \mathrm{min}$ by the strain-stress measurements, according to ISO 525 standard.

The elongation in the elastic state was determined using the mechanical extensometer, with a measurement base of $30 \mathrm{~mm}$. Rectangular samples with a length of $120 \mathrm{~mm}$ and width of $10 \mathrm{~mm}$ were fixed with a clamps distance of $80 \mathrm{~mm}$. For each tensile test the mean value for 5 samples made of SPC and of WPC with 50 wt \% of wood flour has been taken into account.

- Tensile-impact strength measurements of single polymer composites were conducted in compliance with ISO 8256 standard at the temperature $20^{\circ} \mathrm{C}$, using method A and pendulum impact tester HIT 50 by Zwick/Roell, with the yoke $\left(m_{c}\right)$ of $60 \mathrm{~g}$ and pendulum size of $25 \mathrm{~J}$. Samples of the length of $80 \mathrm{~mm}$ and width of $10 \mathrm{~mm}$, with notches of $2 \mathrm{~mm}$ on both sides of the samples (notch radius equaled to $1 \mathrm{~mm}$, angle was $45^{\circ}$ ) have been applied. The measurements were realized for SPC samples fabricated at various processing temperature and for WPC samples containing $50 \mathrm{wt} \%$ of wood filler.

- Moreover, the analysis of the structure of single polymer composites was made on the basis of photographs obtained using Lext OLS 4000 (Olympus) confocal microscope. Photographs were taken for cross-sections of samples pressed at 178,186 and $198{ }^{\circ} \mathrm{C}$.

- The density of SWS, PP, WPC $30 \%$ as well as SPC (obtained at $186{ }^{\circ} \mathrm{C}$ ) and WPC 50\% was determined at temperature of $20^{\circ} \mathrm{C}$, using methyl alcohol of density of $0.792 \mathrm{~g} / \mathrm{cm}^{3}$ as immersion liquid, by means of AD 50 Axis balance equipped with a set allowing the determination of solid density. The size of the investigated samples was $10 \times 10 \times 4 \mathrm{~mm}$.

- The mechanical properties of multilayer polypropylene composite with wood filler and of the reference materials (PP and WPC 30\%) were determined by three point bending test, using the Zwick/Roell Z030 universal testing machine. Multilayer composite samples and reference samples with dimensions of $80 \times 10 \times 4 \mathrm{~mm}$ (length $\times$ width $\times$ height) were investigated. The distance between the supports was $64 \mathrm{~mm}$, the deformation rate by elastic modulus determination was $2 \mathrm{~mm} / \mathrm{min}$ and $50 \mathrm{~mm} / \mathrm{min}$ by the whole test. For each series, five measurements were realized.

\section{RESULTS AND DISCUSSION}

\section{Tensile properties of SPC and WPC sheets}

The tensile test of single polymer composites was realized for samples produced at various compressing molding temperatures, in the range between $174^{\circ} \mathrm{C}$ and $198^{\circ} \mathrm{C}$,

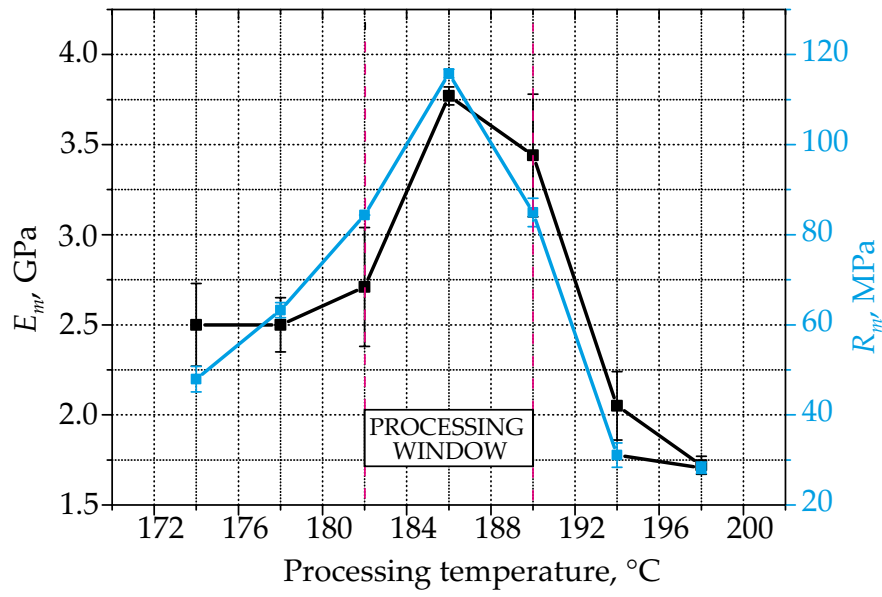

Fig. 1. Elastic modulus $\left(E_{m}\right)$ and tensile strength $\left(R_{m}\right)$ of SPC sheets $v s$. mold temperature 


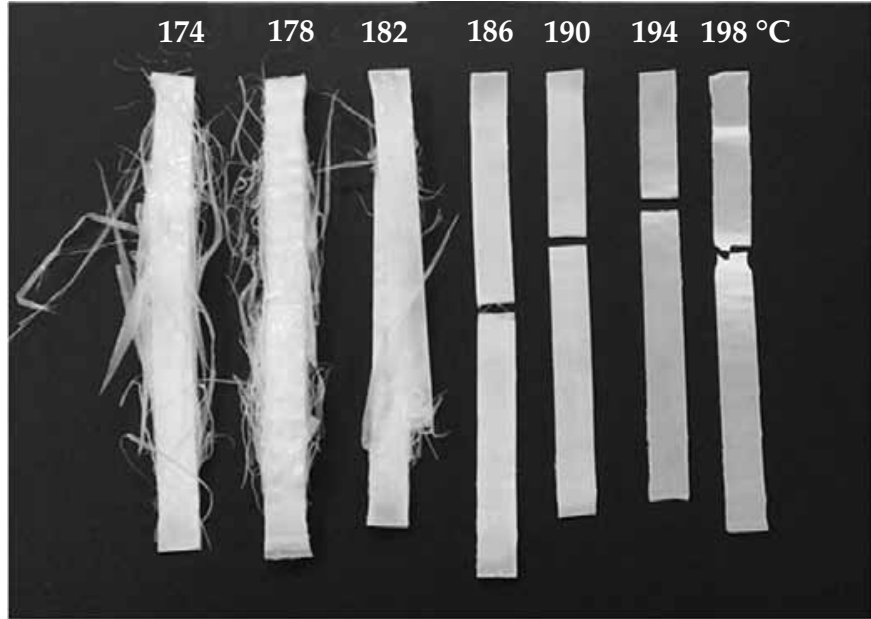

Fig. 2. SPC samples produced at various mold temperature, after stretching tests

with a heating time of $5 \mathrm{~min}$ for each sample. The elastic modulus $\left(E_{m}\right)$ and the tensile strength $\left(R_{m}\right)$ of SPC samples, as a function of processing temperature, are presented on Fig. 1.

As it may be seen the most advantageous properties were achieved for the samples processed at the temperature range between $182{ }^{\circ} \mathrm{C}$ and $190{ }^{\circ} \mathrm{C}$. On the contrary, insufficient melting of the tape surfaces has taken place by processing of the composite at temperature lower than $182{ }^{\circ} \mathrm{C}$, thus it may be stated that the composites didn't reach the required properties. The effect of non-melting of individual layers of PP fabric is clearly visible for samples produced at the mold temperature between $174{ }^{\circ} \mathrm{C}$ and $178{ }^{\circ} \mathrm{C}$ (Fig. 2). Consequently, despite the high content of the orientated phase, single polymer composites produced at too low temperatures are characterized by a relatively low modulus of elasticity and tensile strength, respectively the $E_{m}$ and $R_{m}$ values were 2.5 GPa and $48 \mathrm{MPa}$.

On the contrary, the application of compression molding temperature above $182{ }^{\circ} \mathrm{C}$ resulted in a gradual increase in the analyzed mechanical properties of the composites up to processing temperature equal to $186^{\circ} \mathrm{C}$. The SPC's produced in this temperature are characterized by the highest values of both, the elastic modulus ( $3.75 \mathrm{GPa}$ ) and the tensile strength (115 MPa). Therefore, the range of processing temperature between $182{ }^{\circ} \mathrm{C}$ and $190{ }^{\circ} \mathrm{C}$ may be taken as so called processing window, where both, homogenous composite and high mechanical properties resulting from macromolecular orientation, may be achieved.

The heat delivered to the PP fabric sheets during pressing at temperature above $190{ }^{\circ} \mathrm{C}$ leads to excessive melting of the orientated phase, which results in a noticeable decrease in the $E_{m}$ and $R_{m}$ values of the tested composites. As long as in samples produced at $194{ }^{\circ} \mathrm{C}$ one can expect to have some residue of non-melted tapes, in the case of samples pressed at $198{ }^{\circ} \mathrm{C}$ the reinforcing fabric is almost completely melted. This is demonstrated by the rela-

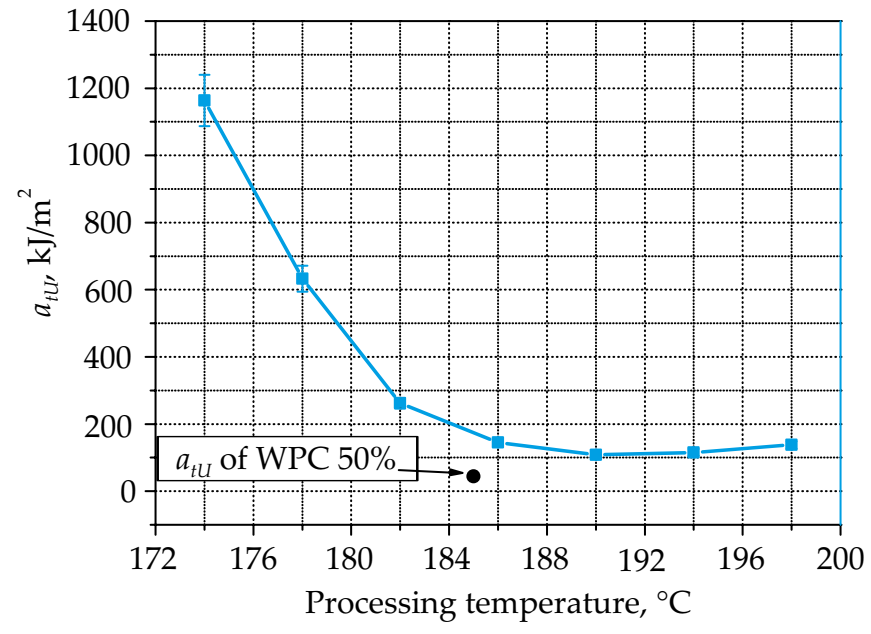

Fig. 3. Tensile-impact strength $\left(a_{t u}\right)$ of SPC sheets $v$ s. mold temperature

tively low values of elastic modulus (1.7 GPa) and tensile strength $(28 \mathrm{MPa})$, comparable to the mechanical characteristics of an isotropic PP. Furthermore, after the static stretching test (Fig. 2) neck forming at the yield point is clearly visible on these samples.

For comparison, the elastic modulus of $50 \mathrm{wt} \%$ wood flour poly propylene composite with a thickness of $2 \mathrm{~mm}$, which was used afterwards as core layer of the three-layer SWS composite, was equal to $3.1 \mathrm{GPa}$. The tensile strength of WPC $50 \%$ was about $25 \mathrm{MPa}$, i.e., revealed a value more than four times lower comparing with the tensile strength of the SPC (115 MPa), presenting the superior properties recorded during static stretching.

\section{Tensile-impact strength}

Figure 3 presents the value $a_{t u}$ (tensile-impact strength) of SPC samples made at various mold temperature and of polypropylene composite with wood filler (WPC 50\%). The SPC samples obtained at mold temperature of $174{ }^{\circ} \mathrm{C}$ were characterized by the highest tensile-impact strength $\left(a_{t U}=1163 \mathrm{~kJ} / \mathrm{m}^{2}\right)$. In the case of samples produced at

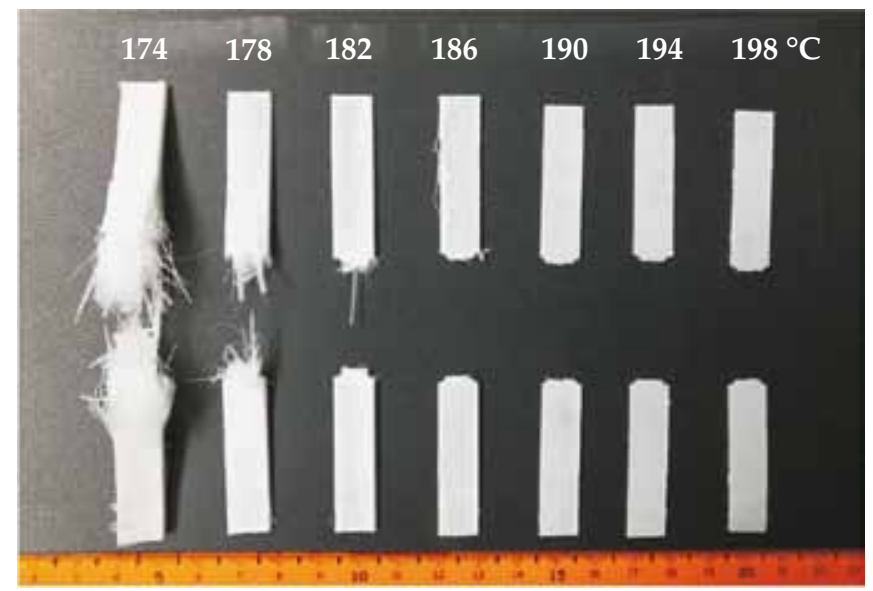

Fig. 4. SPC samples produced at various mold temperature, after tensile-impact tests 
a)

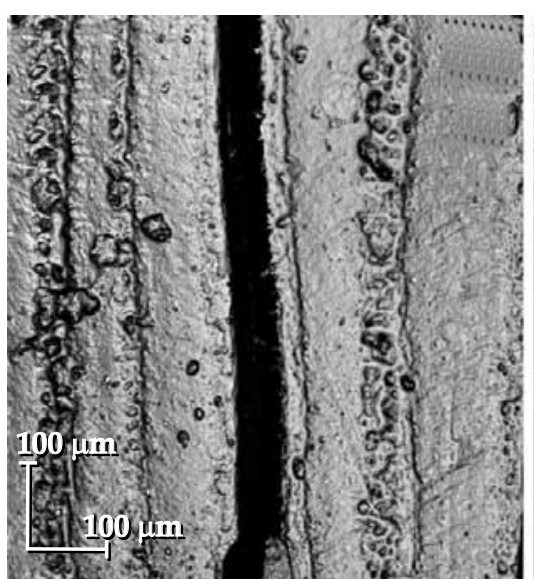

b)

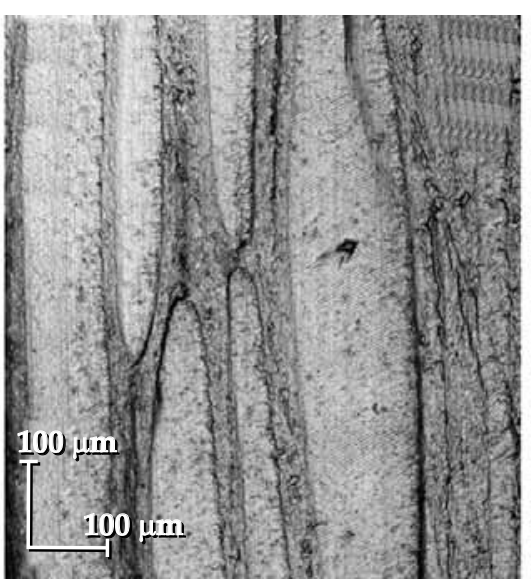

c)

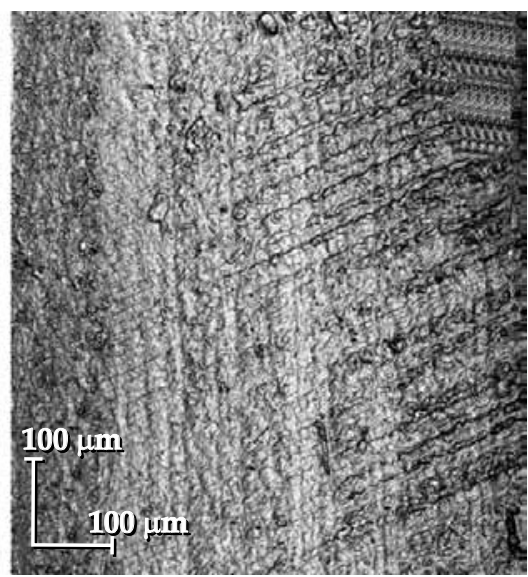

Fig. 5. Structure of SPC samples produced at: a) $174^{\circ} \mathrm{C}$, b) $\left.186^{\circ} \mathrm{C}, \mathrm{c}\right) 198^{\circ} \mathrm{C}$

temperature of $190{ }^{\circ} \mathrm{C}$, the $a_{t U}$ values of single polymer composite rapidly decreased to $108 \mathrm{~kJ} / \mathrm{m}^{2}$. The composites molded at higher temperature are characterized by slightly higher tensile-impact strength. As an example, $a_{t u}$ of the samples produced at $198^{\circ} \mathrm{C}$ is $138 \mathrm{~kJ} / \mathrm{m}^{2}$; on the contrary, the tensile-impact strength of the composite filled with wood flour comes to about $44 \mathrm{~kJ} / \mathrm{m}^{2}$.

Tensile-impact strength of SPC significantly depends on the heat provided to the molded PP fabric during its processing, thereby creating the structure of the composite. It is remarkable that the highest value of tensile-impact strength is characteristic for the samples produced at temperature below $182{ }^{\circ} \mathrm{C}$, thus presenting the weakest adhesion between its layers, as it may be seen on Fig. 4 . Consequently, it can be stated that the highly oriented reinforcing phase in a form of fibers significantly influences the tensile-impact strength of SPC. Moreover, the high values of $a_{t U}$ observed in case of the samples molded at temperature $174{ }^{\circ} \mathrm{C}$ and $178{ }^{\circ} \mathrm{C}$ may be explained by rapid delamination of fibers, absorbing considerable amounts of energy. Contrary, the presence of partially melted PP tapes, surrounded by isotropic matrix in the composite structure, as it is the case by samples produced by mold temperature above $182{ }^{\circ} \mathrm{C}$, may be an origin of

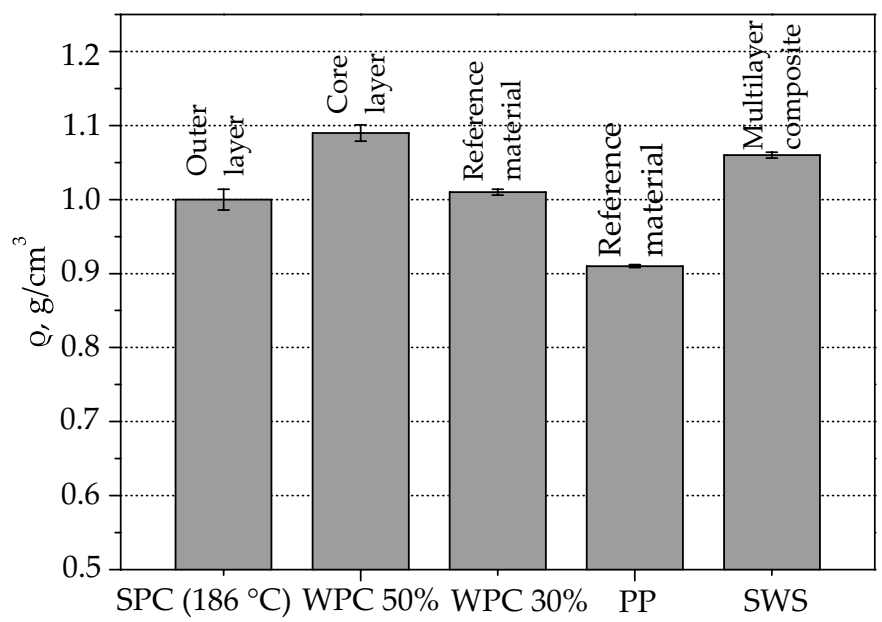

Fig. 6. Density (@) of multilayer composite (SWS) composed of SPC $\left(186^{\circ} \mathrm{C}\right)$ and WPC $50 \%$ in comparison with PP and WPC $30 \%$ lowering of its tensile-impact strength. Therefore, regarding the most favorable conditions for the processing of single polymer composites, it should be noted that the dynamic test may deliver results which are not consistent with results of static mechanical experiments.

\section{Structure}

Figure 5 presents photographs of the structure of chosen samples of SPC composites. In the case of a SPC compressed at $186{ }^{\circ} \mathrm{C}$ (Fig. 5b), parts of unmelted PP tapes surrounded by a polypropylene matrix are clearly visible. The structure of the SPC sample compressed at $198{ }^{\circ} \mathrm{C}$ (Fig. 5c) is more homogeneous. This confirms that oriented reinforcement was melted completely. On the other hand, the delamination effect of the sample with weak adhesion between fabric layers (pressing temperature $174{ }^{\circ} \mathrm{C}$ ) was presented on Fig. 5a.

\section{Density}

The mechanical properties of polymers and its composites is most often related to its density. The density of PP (Moplen HP 500N) and single polymer composite are $0.91 \mathrm{~g} / \mathrm{cm}^{3}$ and $0.99 \mathrm{~g} / \mathrm{cm}^{3}$, respectively; resulting probably from the presence of $10 \mathrm{wt} \%$ of a solid filler in PP used to produce the fabric (raw material for SPC production). The density of WPC $50 \%$, composites used to cerate the core of the multilayer material, came to $1.09 \mathrm{~g} / \mathrm{cm}^{3}$, thus corresponding value of density of the multilayer composite (SWS) is equal to $1.06 \mathrm{~g} / \mathrm{cm}^{3}$ (Fig. 6). For comparison, the density of the reference material WPC $30 \%$ is $1.01 \mathrm{~g} / \mathrm{cm}^{3}$, i.e., about $10 \%$ lower comparing with the corresponding WPC with 50 wt \% of wood filler.

\section{Flexural properties}

Single polymer composite produced at mold temperature of $186{ }^{\circ} \mathrm{C}$ was used to manufacture the multilayer material (SWS), in which SPC was the outer and WPC with 50 wt \% wood flour content was the core layer. For 

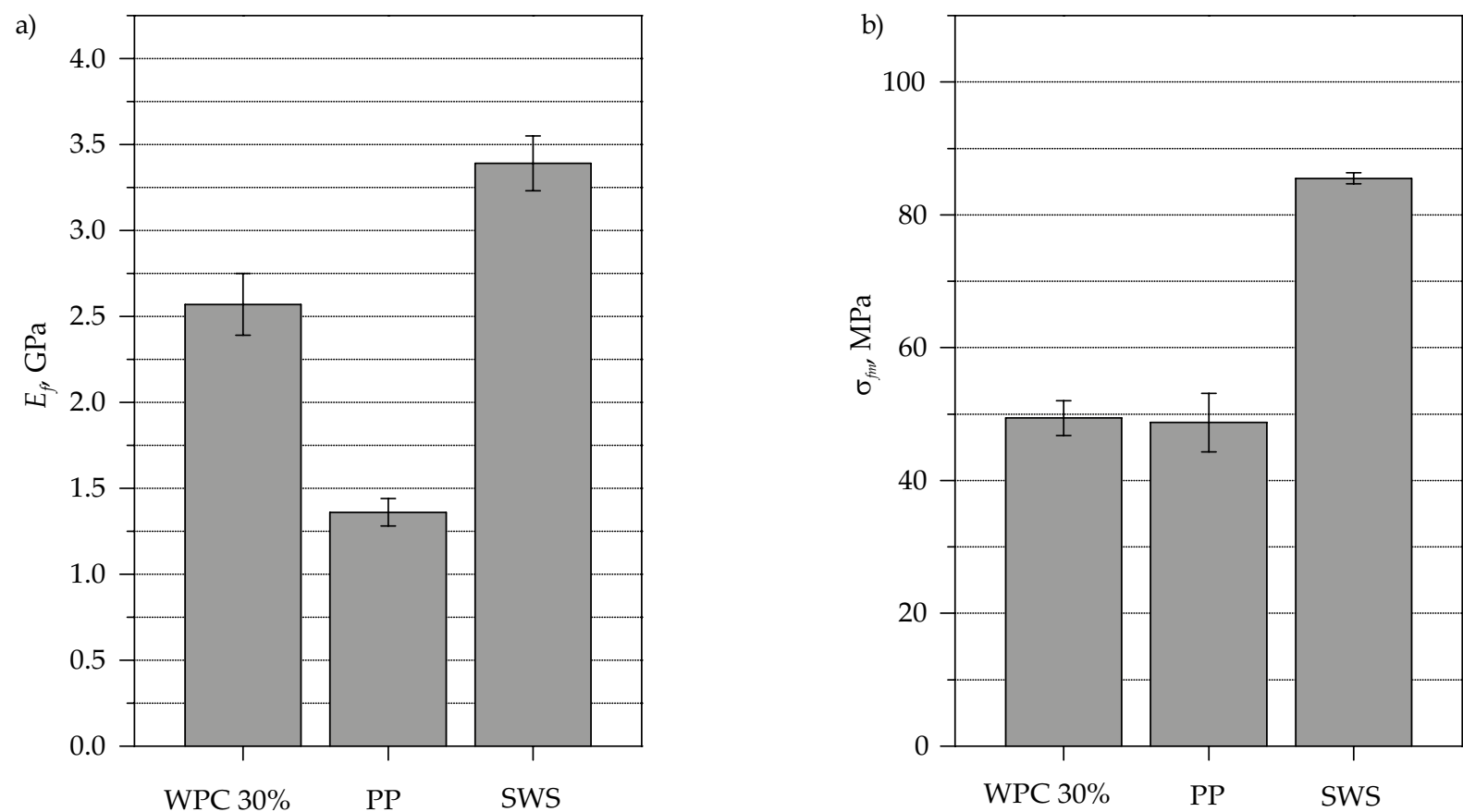

Fig. 7. Flexural: a) modulus $\left(E_{f}\right)$, b) strength $\left(\sigma_{f m}\right)$ of three-layer SWS composite in comparison with PP and WPC $30 \%$

the three-layer composite a significantly higher flexural modulus $\left(E_{f}\right)(3.4 \mathrm{GPa})$ was noted, comparing to unfilled PP (140\%) and WPC 30\% (30\%), with respective values $E_{f}$ of $1.4 \mathrm{GPa}$ and $2.6 \mathrm{GPa}$ (Fig. 7a). The flexural strength value $\left(\sigma_{f m}\right)$ of multilayer material (SWS) was $85 \mathrm{MPa}$ (Fig. 7b), i.e., about $75 \%$ higher than for the pure PP and WPC samples, where the $\sigma_{f m}$ below $50 \mathrm{MPa}$ was observed.

Remarkable observation of bending deformation may be seen on pictures below (Fig. 8). It is worth noting that in the case of WPC with $30 \mathrm{wt} \%$ content of wood filler a clear break, due to the bending deformation was observed for all examined samples (Fig. 8a). No break during flexural test was noted for the PP samples (Fig. 8b), the same effect was also observed by bending of SWS samples (Fig. 8c). The reason for the WPC 30\% cracking is the limited adhesion between the polymer matrix and the filler particles. Despite the higher content of plant filler in the core layer, SWS does not lose its cohesion, neither in the cross-section, nor in the core layer during bending defor- mation. Such an effect may be explained by stress distribution, high tensile and compression stresses in outer layers and low stress in the core of the multilayer composite.

To sum up, an improvement of mechanical properties of SWS was achieved only with a slight increase of density, comparing with the WPC 30\% used as a reference material. Nevertheless, it could be possible to fabricate the multilayer polypropylene composites with lower values of density if a PP fabric without solid fillers was used in the SPC production.

\section{CONCLUSIONS}

The temperature range of effective processing of single polymer composites was determined based on the mechanical tests, using commercial PP fabrics. A satisfactory reinforcements of SPC was obtained at the compression molding temperature in the range between $182{ }^{\circ} \mathrm{C}$ and $190{ }^{\circ} \mathrm{C}$. However, the most advantageous tensile properties have been found for the composites produced a)

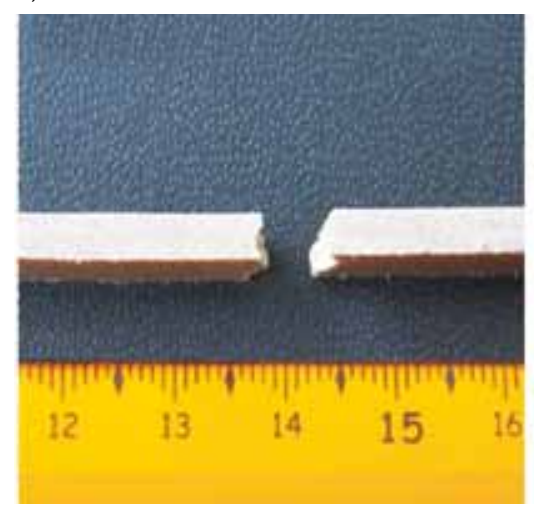

b)

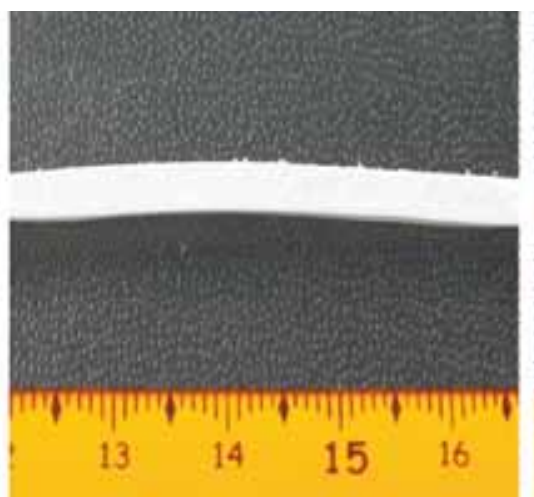

c)

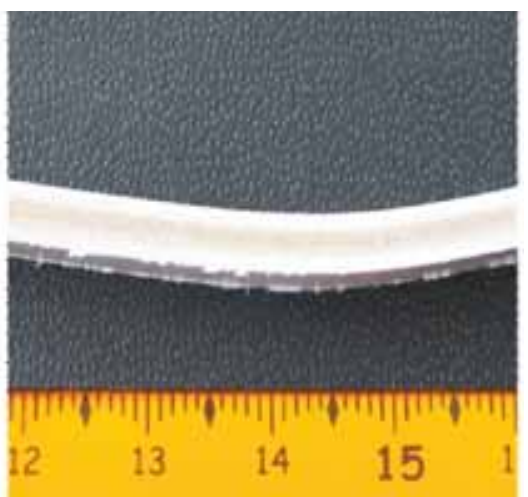

Fig. 8. Samples after flexural test: a) WPC $30 \%$, b) PP, c) SWS 
at $186^{\circ} \mathrm{C}$, with elastic modulus $E_{m}$ of $3.75 \mathrm{GPa}$ and tensile strength $R_{m}$ of $115 \mathrm{MPa}$. The SPC's were used for the fabrication of three-layer polypropylene composites with a core made of WPC, containing $50 \mathrm{wt} \%$ of wood fillers. Such multilayer composites (SWS) reveal suitable mechanical properties, superior comparing to unfilled PP as well as to $30 \mathrm{wt} \%$ plant filler polymer-wood composite.

\section{REFERENCES}

[1] Barczewski M., Dobrzyńska-Mizera M., Dudkiewicz M., Szołyga M.: Polymer International 2016, 65, 1080. http://dx.doi.org/10.1002/pi.5158

[2] Barczewski M., Matykiewicz D., Andrzejewski J., Skórczewska K.: Journal of Advanced Research 2016, 7, 373. https://doi.org/10.1016/j.jare.2016.01.001

[3] Bociąga E., Palutkiewicz P.: Polimery 2012, 57, 38. http://dx.doi.org/10.14314/polimery.2012.038

[4] Castillo L.A., Barbosa S.E., Capiati N.J.: Journal of Polymer Research 2013, 20:152. https://doi.org/10.1007/s10965-013-0152-2

[5] Dulebova L., Garbacz T.: Advances in Science and Technology Research Journal 2017, 11, 66. https://doi.org/10.12913/22998624/76601

[6] Pukanszky B.: "Particulate filled polypropylene: structure and properties" in "Polypropylene: Structure, Blends and Composites" (Ed. Karger-Kocsis J.), Chapman \& Hall, London 1995.

[7] Vollenberg P.H.Th., Heikens D.: Journal of Materials Science 1990, 25, 3089. https://doi.org/10.1007/BF00587655

[8] Rahman N.A., Hassan A., Yahya R., Lafia-Araga R.A.: Fibers and Polymers 2013, 14, 1877. https://doi.org/10.1007/s12221-013-1877-6

[9] Jacob S., Suma K.K., Mendaz J.M. et al.: Macromolecular Symposia 2009, 277, 138. http://dx.doi.org/10.1002/masy.200950317

[10] Czaja K.: „Poliolefiny”, Wydawnictwo Naukowo-Techniczne, Warszawa 2005.

[11] Lewandowski K., Piszczek K., Zajchowski S., Mirowski J.: Polymer Testing 2016, 51, 58. http://dx.doi.org/10.1016/j.polymertesting.2016.02.004

[12] Jiang X., Wang J., Wu G. et al.: Journal of Thermoplastic Composite Materials 2018. https://doi.org/10.1177/0892705718761476

[13] Kociszewski M., Gozdecki C., Wilczyński A. et al.: European Journal of Wood and Wood Products 2012, 70, 113. https://doi.org/10.1007/s00107-011-0531-5

[14] Ndiaye D., Matuana L.M., Mortal-Therias S. et al.: Journal of Applied Polymer Science 2011, 119, 3321. http://dx.doi.org/10.1002/app.32985

[15] Czvikobszky T.: "Polypropylene: An A-Z" (Ed. Karger-Kocsis J.), Kluwer Publisher, Dordrecht 1999, pp. 240-246.

[16] Kale A., Raghu N., Natu H.P. et al:: Journal of Applied Polymer Science 2016, 133, 44 196. https://doi.org/10.1002/app.44196

[17] Kuo P-Y., Wang S-Y., Chen J-H. et al.: Materials and Design 2009, 30, 3489. https://doi.org/10.1016/j.matdes.2009.03.012

[18] Ichazo M.N., Albano C., Gonzalez J. et al.: Composite
Structures 2001, 54, 207.

https://doi.org/10.1016/S0263-8223(01)00089-7

[19] Sobczak L., Lang R.W., Haider A.: Composites Science and Technology 2012, 72, 550.

https://doi.org/10.1016/j.compscitech.2011.12.013

[20] Żenkiewicz M., Moraczewski K., Rytlewski P. et al:: Polimery 2014, 59, 769.

http://dx.doi.org/10.14314/polimery.2014.769

[21] Żenkiewicz M., Moraczewski K., Rytlewski P. et al.: Polimery 2015, 60, 3 .

http://dx.doi.org/10.14314/polimery.2015.003

[22] Abo El-Maaty M.I., Bassett D.C., Olley R.H. et al.: Journal of Materials Science 1996, 31, 1157. https://doi.org/10.1007/BF00353094

[23] Hine P.J., Ward I.M., Jordan N.D. et al.: Polymer 2003, 44, 1117. https://doi.org/10.1016/S0032-3861(02)00809-1

[24] Deng H., Reynolds D.T., Cabrera N.O. et al.: Composites: Part B 2010, 41, 268.

http://dx.doi.org/10.1016/j.compositesb.2010.02.007

[25] Alcock B., Cabrera N.O., Barkoula N.-M. et al.: Journal of Applied Polymer Science 2007, 104, 118. http://dx.doi.org/10.1002/app.24588

[26] Alcock B., Cabrera N.O., Barkoula N.-M., Peijs T.: Applied Composites Materials 2009, 16, 117. http://dx.doi.org/10.1007/s10443-009-9081-y

[27] Sterzyński T., Śledź I.: Polimery 2007, 52, 443.

[28] Andrzejewski J., Szostak M., Barczewski M. et al:: Journal of Applied Polymer Science 2014, 131, 41180. http://dx.doi.org/10.1002/app.41180

[29] Andrzejewski J., Szostak M., Bak T., Trzeciak M.: Journal of Thermoplastic Composite Materials 2014, 29, 1194. https://doi.org/10.1177/0892705714563117

[30] Kościuszko A., Sterzyński T., Piszczek K.: Macromolecular Symposia 2016, 365, 151. http://dx.doi.org/10.1002/masy.20165002

[31] Hine P.J., Ward I.M., Olley R.H., Bassett D.C.: Journal of Materials Science 1993, 28, 316.

[32] Kabeel M.A., Bassett D.C., Olley R.H. et al.: Journal of Materials Science 1994, 29, 4694.

[33] Jordan N.D., Olley R.H., Bassett D.C. et al.: Polymer 2002, 43, 3397. https://doi.org/10.1016/S0032-3861(02)00104-0

[34] Hine P.J., Ward I.M., Teckoe J.: Journal of Materials Science 1998, 33, 2725.

[35] Peijs T.: Materials Today 2003, 6, 30. https://doi.org/10.1016/S1369-7021(03)00428-0

[36] Alcock B., Cabrera N.O., Barkoula N.M., Peijs T.: Applied Composites Materials 2009, 16, 117. https://doi.org/10.1007/s10443-009-9081-y

[37] Alcock B., Cabrera N.O., Barkoula N.M. et al.: Composites: Part A 2007, 38, 147. https://doi.org/10.1016/j.compositesa.2006.01.003

[38] Alcock B., Cabrera N.O., Barkoula N.M. et al.: Composites Science and Technology 2007, 67, 2061. https://doi.org/10.1016/j.compscitech.2006.11.012

[39] Cabrera N.O., Alcock B., Peijs T.: Composites: Part B 2008, 39, 1183. http://dx.doi.org/10.1016/j.compositesb.2008.03.010

Received 22 II 2018. 